\title{
Poverty Alleviation Programmes for Women in Lagos State, Nigeria: An Examination of the Implementation Strategies
}

\author{
POPOOLA O. Olufemi PhD and OSADUME A. Bukola \\ Department of Public Administration, Obafemi Awolowo University, Ile-Ife, Nigeria
}

\begin{abstract}
The study examined the programmes of poverty alleviation and women empowerment in Lagos State; and evaluated the poverty alleviation implementation strategies in Lagos State Ministry of Women Affairs and Poverty Alleviation. Primary data were collected through the administration of questionnaire and conduct of indepth interviews. The study population of 55,011 comprised staff and beneficiaries of the Ministry of Women Affairs and Poverty Alleviation (MWAPA). These included 162 staff and 54,849 beneficiaries according to the directories of the Ministry. Two-stage sampling technique was utilized. A sample size of eighty-one (81) respondents (representing 50\% of the staff of the Ministry) while four hundred (400) beneficiaries of the Ministry that had benefited from the Ministry were sampled using Taro Yamane formula. In addition, in-depth structured interviews were conducted with 10 members of staff who were directly involved in skill acquisition programmes on programme performance and challenges facing the Ministry at reducing poverty in Lagos State. These included the Honourable Commissioner of the Ministry of Women Affairs and Poverty Alleviation; the Permanent Secretary; four Heads of Department (Women Department, Women Development Centre, the Planning, Research and Statistics Department, and Poverty department), and the assistant heads of the four departments mentioned while 10 beneficiaries were interviewed on programme performance and benefits derived from the Ministry. Data collected were analysed using percentage, mean, standard deviation, and relative impact index. The result showed that the strategies adopted by WAPA was that they monitor and followup beneficiaries regularly for effective performance (96.2\%); the resources made available by Government in terms of human, financial and material are adequate for the smooth running of the programme (56.5\%); Government adequately finances the procurement of tools and materials for the beneficiaries (78.2\%); beneficiaries are given adequate vocational skills, training, and other WAPA programmes necessary before graduating(52.2\%); entrepreneurship development programmes are regularly organised for the beneficiaries(39.1\%); and is regular monitoring/follow-up by the WAPA officials(34.8\%). The study concluded that the programmes of the Ministry of women affairs and poverty alleviation on poverty reduction and empowerment of women in Lagos State had been fairly successful.
\end{abstract}

Key Words: Gender, Gender equality, Gender equity, Poverty, Poverty alleviation.

DOI: $10.7176 / \mathrm{RHSS} / 9-18-14$

Publication date:September $30^{\text {th }} 2019$

\section{Introduction}

One of the issues foremost in the International Development Agenda of the 21 st century is Poverty Alleviation. Ebuara, Ozurumba and Udida (2006) opined that poverty alleviation is the reduction of the components which add to poverty. As indicated by them, furnishing citizens with those amicable open doors that would empower them to give fundamental methods for accomplishing financial freedom is poverty alleviation.

Poverty implies denial of the means of subsistence. The indicators of poverty are quite many; they include absence of the access to basic social services like health and education, insufficient circulation of resources, low life expectancy, food scarcity and lack of participation in decision making process. Looking at the social facets of poverty, these include denial of needed information, quality education, power in politics and good medical care. Furthermore, poverty is considered a situation of imbalanced social standing, and discriminatory communal relations, manifesting in segregation, reliance, weakened capability to be involved, and to improve important networks with others in the community. Poverty is the lack of the basic necessities of life which determines a qualitative living. These include food, shelter, and safe drinking water. Others are inability of an individual to be gainfully employed and inability to overcome the menace of poverty and/or to gain the admiration of fellow citizens.

Many women in the past years are overwhelmed with challenges of joblessness, lack of source of income, widowhood, and being a single parent. Though the tasks are enormous, women still play their roles in development of the nation as well as all other aspects of life and this has been quite notable. Even though success has been recorded in the aspect of increasing the capacities of the female gender, their economic and political 
decision- making impact still seem insignificant. The United Nations Development Programme, in its Human Development Report in 2005 highlighted part of the examples to drive home the point that despite the substantial growth in strengthening women's capabilities, both the male and female gender still live in an unequal world.

The UN meeting underlined the need to guarantee that gender orientation correspondence is an essential objective in every aspect of social and economic improvement incorporates the dialogue of poverty and its decrease. Correspondingly, the World Bank (1999) additionally made goals to address poverty concerning the diverse impacts on women. One essential objective for the World Bank group was the update of laws and managerial practices to guarantee women's equivalent rights and access to financial assets. Ugo and Ukpere (2009) agreed that gender mainstreaming fortifies women's dynamic inclusion in poverty alleviation through connecting women's abilities and commitments with full scale economic issues.

Hiliary Clinton, an ex-first lady of United States of America said a nation whose Government does not make empowering women one of their primary concerns will be limited in development. She further attested to the fact that a nation where only men are given opportunity for economic, empowerment continues in a circle of dependability but when women are empowered, the family and society at large are empowered. (Interview with MO Abudu; Moments with MO, 2017). Women development is essential and it is a process where women energise their ability and capacity so as to be in charge of their lives and take responsibility for it. Poverty alleviation for women places them on a good ground. Being financially empowered, it enables them to be able to raise their wards properly and they will financially free.

Mostly, when a woman is no longer financially impoverished, their status often changes. They, being economically empowered, can then move on in life handling activities that demonstrate financial independence, developing their capacity to take decisions. In many developing countries, the conditions of women in specific areas of actions have worsened compared to their male counterparts. Two out of the Sustainable Development Goals (SDGs) numbering eight has to have to do with eliminating absolute poverty and starvation and also discouraging gender inequality but parity and women empowerment. Those nations who put a lot in developing the status of women socially and economically have lesser poverty to deal with. Because of its resultant effects, poverty has become a source of worry. Though poverty affects both men and women, women seem to be more susceptible to poverty because of cultural elements that have had negative influence on women.

Reasonable efforts to alleviate poverty particularly among women have been made by concerned groups such as the Government, Non-Governmental Organizations, Women Activists and concerned individuals but the issue is still there. Ugly experiences of women have negative impact on them, kids and other relatives. Poverty denies so many women of enjoying the basic privileges in life like quality education, quality healthcare, participation in political process and power to control resources.

Lagos population, as a city, happens to be the highest in Nigeria, and Nigeria's population as a country is the highest in sub-Saharan Africa which is also named the ninth most- populous nation globally (Wikipedia). Though Nigeria is endowed with abundant natural and human resources, a lot of people live below average and the gap between the rich and the poor is too wide. Nigeria is believed to be poor due to mismanagement of resources. Resources placed in the hands of poor women results in huge development payoffs and also encourage gender equality in the family and in society. Increasing women's opportunities in public service, agriculture, finance, and other sectors speed up economic development. This helps to allay the effects of existing and imminent financial crises. Poverty is a menace that no country neglects because of its effects on human development.

The women affairs and poverty alleviation (WAPA) programmes were made to improve the living conditions of ladies and children through economic empowerment and sustainable projects that would lead to independence. It is focused on ladies advancement and poverty lessening as methods for achieving reasonable economic development. Among the objectives is the annihilation of extreme poverty and hunger, advancement of gender equity and empowerment of ladies. The central responsibilities of women affairs and poverty alleviation programmme include liaising with voluntary associations/international bodies on ladies programmes, planning the activities of women non-governmental associations, forming and promoting ladies co-operative societies, ladies education vocational and functional training and advancing small scale enterprises. Others are stimulating commercial activities among ladies' groups; organizing ministerial projects on ladies' databank/data centre on women programs; and giving technical assistance on women programmes. Apart from these, training and skill acquisition for ladies and others needing special help and advancing commercial exercises of women in 
rural regions, setting up income generating programmes for ladies/advancing and promoting arts and crafts export are als crucial responsibilities.Mention must also be made that supervising women development centres, overseeing ladies improvement and empowering solidarity among ladies groups and giving and overseeing microcredit plans to poverty alleviation projects and employment creation/poverty alleviation are equally germane.

\section{Literature Review}

The term 'gender' means set of abilities and behaviours expected of men and women according to their ethos. Somebody's public individuality is shaped according to these expectations. These expectations originate from the notion that certain abilities, behaviour, structures, necessities and roles are 'natural' for men, while certain other qualities and roles are 'natural' for women. Gender is not biological - that is how male and female are not borne with different abilities and knowing how they should appear in public, talk, act, think and respond to situations. All these are picked up from their environment. This is what prepares them for the future as with reference to their obligations as male or female. These roles and anticipations vary from one culture to the other and at different times in history. They may, as a matter of time, change. Gender is not a synonym for 'women'!

Equality refers to treating male and female gender equally according to their privileges, legislation and policies as well as in making equal access to and control of resources and services available within the individual households and the public. It is a basic human right.

The United Nations System in Nigeria in Gender Briefing Kit (2013) explained that gender equality entails the acknowledgement of the issue that the overall systems nowadays (social, economic, cultural and political) are biased as regards the male and female genders. Gender equality indicates same opportunity in life for both genders, as well as the capability to play a part in the public and influence it. Gender equity is a policy and distinctive measures towards womenfolk aiming to compensate them for the social and historical inequality that rob them of having the right of entry to the same prospects, for instance, positive discrimination, quota system, and so on. These actions stay grounded on the acknowledgement of women and men diverse positions and circumstance. This is a conclusion that attaining a balance in a practical sense may demand sensitivity and skills in the handling of women. Therefore, these are a chain of actions that identify necessity in reallocating power and resources. Gender Equity therefore complements and contributes to the effective implementation of gender equality. They are both compatible.

"The Wealth of Nations" by Adam Smith in 1776 debated that poverty is the incapability to pay for, "not only the commodities which are indispensably necessary for the support of life, but whatsoever it is the tradition of the nation renders for reliable persons, even that of the lowest order, to be without". J.K. Galbraith (1958) however debated that being poverty stricken is when their earnings are just enough to get by and is markedly behind that of their community.

Poverty encompasses starvation and the absence of accommodation. It also means being sick and inaccessible to a physician. Poverty as well, means lack of opportunity for quality education and lacking the ability to read. It is lacking employment and being anxious about the future. Poverty is when someone loses a child due to sickness/illness as a result of lack of potable water. Poverty is helplessness/hopelessness, having no representation as well as liberty. Poverty is an impoverished condition, a condition of destitution as well as the scarcity of resources through an extensive array of conditions. Poverty is viewed by the United Nations System in Nigeria (2013) essentially as being denied choices and prospects. It is the abuse of human self-worth.

To the World Bank (1999), poverty is evident as deprivation in well-being and encompasses many scopes. It comprises near to the ground earnings also incapable of gaining elementary resources required for continued existence and self-worth. Also, the World Bank perceives poverty as including lowliness in healthiness and learning, insignificant accessibility to potable water as well as hygiene and lack of physical safety. It also means not having a voice and unsatisfactory capability and prospect to enhanced and improved existence. Extreme poverty, as a condition, is viewed as a severe denial of primary needs. These comprise nourishment, potable water, hygiene amenities, healthcare, housing, learning and information. The subject 'extreme poverty' is synonymously termed as 'absolute poverty'. The World Bank (1999:12) in articulating poverty from gender perspective states that "in certain cases, the gender scopes of helplessness remained expressed, and consequences 
borne by both the male and female gender at all stages of growth. In Nigeria, poor households were seen to be characterized by the inability of men to fulfill their role as providers.

According to OECD (2000: 32), Female poverty is more widespread and characteristically more austere than male poverty." It additionally specified that women undergo violence by men on a high level. They are more prone to being illiterate and socially and politically debarred in their various societies. Therefore, generally, there is the difference in the abilities of women and men in overcoming poverty.

\section{Theoretical Framework}

This work is hinged on Structural Theory of Poverty by Karl Marx (1953). He propounded that for any policy meant to be executed; there must be a structure or institution set up in implementing it. For every one of the strategies for women in respect of their part in alleviating poverty, the structures or institutions that are set up must be satisfactory, viable and productive so as to achieve its objectives.

Many of the writings on poverty (Narayan, et al, 2000; Kankwenda, 2001; Aliyu, 2002) now recommend that the economic framework should be organized in such a way that poor individuals should be reckoned with irrespective of how skilled or less-skilled they might be. Halfway the issue is the way that minimum wages don't enable single parents or their families to be financially independent (Jencks 1996:72). The issue of the working poor is progressively observed as a wage issue connected to structural hindrances keeping poor families from securing better employment, complicated by a limited number of employment close to workers and absence of development in parts supporting lower talented employments (Tobin, 1994).

\section{Methodology}

The study examined the programmes of poverty alleviation and women empowerment in Lagos State as well as evaluated the poverty alleviation implementation strategies in Lagos State Ministry of Women Affairs and Poverty Alleviation. It also identified the challenges of poverty alleviation on poverty reduction and women empowerment in the study area. These were with a view to providing information on the impact of poverty alleviation and women empowerment in Lagos State. Primary data were collected through the administration of questionnaire and conduct of in-depth interviews. The study population of 55,011 comprised staff and beneficiaries of the Ministry of Women Affairs and Poverty Alleviation (MWAPA). These included 162 staff and 54,849 beneficiaries according to the directories of the Ministry. Two-stage sampling technique was utilized. A sample size of eighty-one (81) respondents (representing 50\% of the staff of the Ministry) while four hundred (400) beneficiaries of the Ministry that had benefited from the Ministry were sampled using Taro Yamane formula. In addition, in-depth structured interviews were conducted with 10 members of staff who were directly involved in skill acquisition programmes on programme performance and challenges facing the Ministry at reducing poverty in Lagos State. These included the Honourable Commissioner of the Ministry of Women Affairs and Poverty Alleviation; the Permanent Secretary of the same Ministryfour Heads of Department (Women Department, Women Development Centre, the Planning, Research and Statistics Department, and Poverty Department), and the assistant heads of the four departments mentioned while 10 beneficiaries were interviewed on programme performance and benefits derived from the Ministry. Data collected were analysed using percentage, mean, standard deviation, and relative impact index. 


\section{Results}

Objective : Evaluate the poverty alleviation implementation strategies for women in Lagos State

Table 1: Monitoring and Follow-up Strategies of WAPA

\begin{tabular}{|c|c|c|c|c|c|c|c|}
\hline \multirow[t]{2}{*}{ Variables } & \multirow{2}{*}{$\begin{array}{l}\text { Strongly } \\
\text { Agreed } \\
\text { F(\%) }\end{array}$} & \multirow{2}{*}{$\begin{array}{l}\text { Agreed } \\
\text { F(\%) }\end{array}$} & \multirow{2}{*}{$\begin{array}{l}\text { Undecided } \\
\mathbf{F}(\%)\end{array}$} & \multirow{2}{*}{$\begin{array}{l}\text { Disagreed } \\
\text { F(\%) }\end{array}$} & \multirow{2}{*}{$\begin{array}{l}\text { Strongly } \\
\text { Disagreed } \\
\text { F(\%) }\end{array}$} & \multicolumn{2}{|c|}{ Descriptive Statistics } \\
\hline & & & & & & Mean & $\begin{array}{c}\text { Standard } \\
\text { Deviation }\end{array}$ \\
\hline $\begin{array}{l}\text { WAPA have } \\
\text { enough programmes } \\
\text { to alleviate poverty } \\
\text { among women }\end{array}$ & $33(47.8)$ & $24(34.8)$ & $3(4.3)$ & $9(13.0)$ & Nil & 3.22 & 1.020 \\
\hline
\end{tabular}

Source: Fieldwork 2018

This section examined the programmes targeted towards the eradication of poverty in Lagos State if it was adequate to alleviate poverty among women. The results showed that the programmes designed by WAPA were indeed enough to solve the problems of poverty with $57(82.6 \%)$ agreeing to the assertion. 3(4.3\%) were undecided on the view while $9(13 \%)$ disagreed. This implies that for the reduction of poverty in Lagos State, the strategy of creating enough programmes to help empower these women were in place and functional. The mean value and standard deviation for this assertion are (3.22 and 1.020) respectively.

Table 2: Level of resources made available by the Government in alleviating poverty in Lagos State among women

\begin{tabular}{|c|c|c|c|c|c|c|c|}
\hline \multirow[t]{2}{*}{ Variables } & \multirow{2}{*}{$\begin{array}{l}\text { Strongly } \\
\text { Agreed } \\
\mathbf{F}(\%)\end{array}$} & \multirow{2}{*}{$\begin{array}{l}\text { Agreed } \\
\text { F(\%) }\end{array}$} & \multirow{2}{*}{$\begin{array}{l}\text { Undecided } \\
\text { F(\%) }\end{array}$} & \multirow{2}{*}{$\begin{array}{l}\text { Disagreed } \\
\text { F(\%) }\end{array}$} & \multirow{2}{*}{\begin{tabular}{l|} 
Strongly \\
\\
Disagreed \\
F(\%) \\
\end{tabular}} & \multicolumn{2}{|c|}{$\begin{array}{l}\text { Descriptive } \\
\text { Statistics } \\
\end{array}$} \\
\hline & & & & & & mean & $\begin{array}{l}\text { Standard } \\
\text { Deviation }\end{array}$ \\
\hline $\begin{array}{l}\text { Resources made } \\
\text { available by } \\
\text { Government in } \\
\text { terms of human, } \\
\text { financial and } \\
\text { materials are } \\
\text { adequate for the } \\
\text { smooth running } \\
\text { of } \\
\text { Programme the }\end{array}$ & $15(21.7)$ & $39(56.5)$ & $3(4.3)$ & $6(8.7)$ & $6(8.7)$ & 2.95 & 0.843 \\
\hline
\end{tabular}

Source: Fieldwork 2018

In evaluating the level of resources made available by Government in terms of human financial and material are adequate for the smooth running of the programme, 15(21.7\%) strongly agreed, 39(56.5\%) agreed, 3(4.3\%) were undecided on the issue, 6(8.7\%) disagreed while $6(8.7 \%)$ strongly disagreed. These findings corroborated the fact that Lagos State is doing fairly enough financially in order to reduce poverty in Lagos State among women. The mean value and standard deviation are (2.95 and 0.843 ) respectively. 
Table 3: Extent of Government financing the procurement of tools

\begin{tabular}{|l|l|l|l|l|l|l|l|}
\hline Variables & Strongly & Agreed & Undecided & Disagreed & Strongly & \multicolumn{2}{l|}{ Descriptive } \\
\hline Agreed & $\mathbf{f}(\%)$ & $\mathbf{f}(\%)$ & $\mathbf{f}(\%)$ & $\mathbf{f}(\%)$ & $\mathbf{f}(\%)$ & Statistics \\
\hline $\begin{array}{c}\text { Government } \\
\text { 1 adequately } \\
\text { ce finance the } \\
\text { ee procurement } \\
\text { ototttools and } \\
\text { te materials for } \\
\text { beneficiaries }\end{array}$ & $21(30.4)$ & $33(47.8)$ & $3(4.3)$ & $6(8.7)$ & $6(8.7)$ & 3.04 & 0.888 \\
\hline
\end{tabular}

Source: Fieldwork, 2018

These results showed that Government adequately finances the procurement of tools and materials for the beneficiaries. It was observed that $21(30.4 \%)$ rated to a very high extent; and with the support of $33(47.8 \%)$ of the respondents who rated to a high extent. Thus an aggregate of $54(78.2 \%)$ of the respondents, which was far away from $3(4.8 \%)$ who were undecided, and $12(17.4 \%)$ who rated low. The mean value is 3.04 while the standard deviation is 0.898 .

Table 4: Evaluation of the vocational skills, training of the various WAPA programmes given to the beneficiaries before graduating

\begin{tabular}{|c|c|c|c|c|c|c|c|}
\hline \multirow[t]{2}{*}{ Variables } & \multirow{2}{*}{$\begin{array}{l}\text { Strongly } \\
\text { Agreed } \\
\mathrm{F}(\%)\end{array}$} & \multirow{2}{*}{$\begin{array}{l}\text { Agreed } \\
\mathrm{F}(\%)\end{array}$} & \multirow{2}{*}{$\begin{array}{l}\text { Undecided } \\
\mathrm{F}(\%)\end{array}$} & \multirow{2}{*}{$\begin{array}{l}\text { Disagreed } \\
\mathrm{F}(\%)\end{array}$} & \multirow{2}{*}{$\begin{array}{l}\text { Strongly } \\
\text { Disagreed } \\
\mathrm{F}(\%)\end{array}$} & \multicolumn{2}{|c|}{$\begin{array}{l}\text { Descriptive } \\
\text { Statistics }\end{array}$} \\
\hline & & & & & & Mean & $\begin{array}{l}\text { Standard } \\
\text { Deviation }\end{array}$ \\
\hline $\begin{array}{l}\text { Beneficiaries } \\
\text { are given } \\
\text { adequate } \\
\text { vocational } \\
\text { skills, training } \\
\text { of the various } \\
\text { WAPA } \\
\text { Programmes } \\
\text { before } \\
\text { graduating }\end{array}$ & $36(52.2)$ & $30(43.5)$ & Nil & $3(4.3)$ & nil & 3.43 & 0.727 \\
\hline
\end{tabular}

Source: Fieldwork, 2018

Beneficiaries are given adequate vocational skills, training, and other WAPA programmes necessary before graduating, 36(52.2\%) strongly agreed, 30(43.5\%) agreed, while 3(4.3\%) disagreed. This result also showed that beneficiaries are well trained in different skills for financial empowerment. The mean value is 3.43 and the standard deviation is 0.727 .

Table 5: Extent of Entrepreneurship Development Programmes organized for the

beneficiaries

\begin{tabular}{|c|c|c|c|c|c|c|c|}
\hline \multirow[t]{2}{*}{ Variables } & \multirow{2}{*}{$\begin{array}{l}\text { Strongly } \\
\text { Agreed } \\
\text { f(\%) }\end{array}$} & \multirow{2}{*}{$\begin{array}{l}\text { Agreed } \\
\text { f(\%) }\end{array}$} & \multirow{2}{*}{$\begin{array}{l}\text { Undecided } \\
\mathbf{f}(\%)\end{array}$} & \multirow{2}{*}{$\begin{array}{l}\text { Disagreed } \\
\mathbf{f}(\%)\end{array}$} & \multirow{2}{*}{$\begin{array}{l}\text { Strongly } \\
\text { Disagreed } \\
\mathbf{f}(\%)\end{array}$} & \multicolumn{2}{|c|}{$\begin{array}{l}\text { Descriptive } \\
\text { Statistics }\end{array}$} \\
\hline & & & & & & mean & $\begin{array}{l}\text { Standard } \\
\text { Deviation }\end{array}$ \\
\hline $\begin{array}{l}\text { Entrepreneurship } \\
\text { development } \\
\text { programmes are } \\
\text { regularly } \\
\text { organized for the } \\
\text { beneficiaries }\end{array}$ & $27(39.1)$ & $27(39.1)$ & Nil & $12(17.4)$ & $3(4.3)$ & 3.00 & 1.087 \\
\hline
\end{tabular}

Source: Field work, 2018

The result showed that entrepreneurship development programmes are regularly organised for the beneficiaries, 27(39.1\%) strongly agreed, 27(39.1\%) agreed, 12(17.4\%) disagreed while 3(4.3\%) strongly 
disagreed. The interpretation is that entrepreneurship development programmes were truly part of the strategies in the reduction of poverty in Lagos State. The mean value is 3.00 while the standard deviation is 1.087.

Table 6: Evaluation of the monitoring of the beneficiaries by the WAPA officials

\begin{tabular}{|c|c|c|c|c|c|c|c|}
\hline \multirow[t]{2}{*}{ Variables } & \multirow{2}{*}{$\begin{array}{l}\text { Strongly } \\
\text { Agreed }\end{array}$} & \multirow{2}{*}{$\begin{array}{l}\text { Agreed } \\
\text { F(\%) }\end{array}$} & \multirow{2}{*}{$\begin{array}{l}\text { Undecided } \\
\mathbf{F}(\%)\end{array}$} & \multirow{2}{*}{$\begin{array}{l}\text { Disagreed } \\
\text { F(\%) }\end{array}$} & \multirow{2}{*}{$\begin{array}{l}\text { Strongly } \\
\text { Disagreed } \\
\text { F(\%) }\end{array}$} & \multicolumn{2}{|c|}{$\begin{array}{l}\text { Descriptive } \\
\text { Statistics }\end{array}$} \\
\hline & & & & & & Mean & $\begin{array}{l}\text { Standard } \\
\text { Deviation }\end{array}$ \\
\hline $\begin{array}{l}\text { There is regular } \\
\text { monitoring of } \\
\text { the beneficiaries } \\
\text { by the officials }\end{array}$ & $15(21.7)$ & $24(34.8)$ & Nil & $21(30.4)$ & $9(13.0)$ & 2.47 & 1.162 \\
\hline
\end{tabular}

Source: Field Work, 2018

The result showed regular monitoring/follow-up by the WAPA officials, $15(21.7 \%)$ strongly agreed, 24(34.8\%) agreed, 21(30.4\%) disagreed while 9(13.0\%) strongly disagreed. This implies that relatively, there was regular monitoring/follow-up of the beneficiaries by MWAPA for the achievement of the objectives. The mean value and standard deviation are 2.47 and 1.162 respectively.

\section{Qualitative Analysis}

The quantitative data were also complimented with the qualitative data gathered from the interview sessions with some Staff and beneficiaries of the Ministry of Women Affairs and Poverty Alleviation. According to the head of poverty department who also doubles as an assistant Director in the Ministry, WAPA programme is all about poverty reduction, women empowerment, and skill acquisition. He attested to the fact that there is collaboration between WAPA and other organizations both locally and internationally.

The Assistant Chief Planning Officer of the Ministry (assistant head of planning, research and statistics) also attested to the responsibility of the Ministry which is to improve the living standard of people of Lagos State with primary focus on all categories of women through economic empowerment and sustainable programmes that will lead to self-employment and economic reliance and was said to be established in 1999 . He also attested to WAPA collaborating with other agencies both locally and internationally.

The Permanent Secretary, Ministry of Women Affairs and Poverty Alleviation in her own case said the Ministry was established over thirty years ago and that the main purpose was to alleviate and eradicate poverty in the rural and urban society. She also mentioned in the affirmative that there was collaboration with other donor agencies by WAPA both locally and internationally.

The beneficiaries that were interviewed affirmed that they had benefited from the Ministry in terms of self-improvement and self-reliance. They all attested to the fact that even though there was improvement in their lives, their monthly income was still not enough to cater for their basic needs. Only one of them said the income was fairly enough.

During the interview with the Permanent Secretary concerning the implementation strategies, she mentioned that there were adequate resources available in terms of human, financial and material for the smooth running of the programme as well as supports from individuals, Local Government, State and international donors towards empowerment efforts and poverty alleviation.

The Assistant Director and Head of Poverty Department, on the other hand, in his opinion said the resources were usually not enough but however agreed that there were supports from individuals, Local Government, State and international donors towards the empowerment efforts and poverty alleviation among women. 


\section{Major Findings}

The main thrust of this study was to assess poverty alleviation implementation strategies for women in Lagos State (WAPA) between t 2006 and 2015. The study found out that entrepreneurial development, vocational skill acquisition and monitoring, among others, were the strategies of poverty reduction among women in Lagos State.

Findings of the study further revealed that the participants were given adequate vocational and entrepreneurial skills for self-reliance. $56.5 \%$ also agreed to reasonable resources in terms of human, material and financial resources had been invested into the programme. Another notable finding was Sthat $47.4 \%$ of the respondents opined that WAPA had enough programmes to alleviate poverty. This confirmed the work of Fapohunda (2012) that a lot of resources and efforts have been put into the alleviation of poverty in Lagos State.

\section{Concluding Remarks}

The study concluded that poverty alleviation and the empowerment of women in Lagos was one that had multiple facets. The Women and Poverty Alleviation Programme has succeeded thus far because it has had the support of relevant government machinery and agencies as well as NGOs. The fight though has not been won. It is evident that the programme can only do so much but without a national concern about eradicating poverty and empowering women. The challenges faced by the programme will continue to rise taking into consideration the cosmopolitan nature of Lagos. Nevertheless, a lot of efforts and resources have gone into achieving the goals of the programmes especially with regards to poverty reduction, women empowerment, and gender equality. The programme has set out projects for the years to come. Some of them include the establishment of more skills acquisition centres particularly in the rural areas and the extreme reduction of poverty and hunger. Achieving these would not only require the support of all agencies that have been supportive over the years but would also need adequate and appropriate staffing and the timely release of funds. Hopefully, in years to come and with more achievements to celebrate, poverty alleviation would have succeeded to a large extent in Lagos and this would contribute positively to changing the lives of women. The way forward to reduced poverty among females involves a combination of the efforts of different stake holders including the government, NGOs, women activists, all members of the population and the women themselves.

In the light of the above concluding remarks, the following recommendations are made:

1. There should be prompt release of funds and an upward review of the funds made available for implementation to be able to make provision for the population explosion in the study area.

2. Establishment of database for easy access to information has become imperative.

3. Implementation of strategic programmes like women cooperative societies, promotion of small-scale industries/commercial activities amongst women groups must be carried out.

4. There should be creation of more awareness programmes most especially among the rural women in order for them to know the existence of WAPA and the various programmes available to them for thereduction of poverty and their empowerment.

5. More vocational centers should be set up and in more Local Government Areas for easy access of the beneficiaries to the empowerment programmes.

6. Provision should be made for start-up capital and equipment so the beneficiaries do not end up in the same poor level if they cannot establish in their different trades.

7. There should be more collaboration of WAPA with the private sector and international partners. This will enable it to achieve its empowerment programmes in the area of strategic programmes in the reduction of poverty and finances. The Government cannot do it all. 


\section{References}

Aliyu, A. (2002): Re-Structuring of the Poverty Alleviation Activities of the Federal Government of Nigeria National Poverty Eradication Programme, Abuja. NAPEP

Galbraith, J.K (1958). The Affluent Society. Boston: Houghton Mifflin.

Jencks, C. (1996). Can We Replace Welfare With Work? In M. R. Darby (ed), Reducing Poverty in America. Thousand Oaks: Sage.

Kankwenda,M. (2001): The Role of Developmental Partners in the Implementation of Poverty Eradication Programme in FGN (2001) National Poverty Eradication Programme(NAPEP Proceeding of the First Retreat for Executive Governors and State Coordination of NAPEP, $22^{\text {nd }}-24^{\text {th }}$ June. Nicon Hilton, Abuja

Marx, K. (1953): Marx-Engels-Werke (MEW). Berlin: Dietz

Narayan, D. et al (2000): Voices of The Poor: Can Anyone Hear Us? World Bank: New York

Organisation for Economic Co-operation and Development (2001)“Development Assistance Committee (DAC) Guidelines on Poverty Reduction” Policy Statement by the DAC on Poverty Reduction. Paris.

Smith, Adam (2007): The Wealth of Nations. Petersfield: Harriman House

The United Nations System in Nigeria (2013) Gender Equality Briefing Kit.

Tobin, J. (1994). Poverty in Relation to Macroeconomic Trends, Cycles, Policies. in S. H.D Amkor-Ikpa, M. (2006). Strategies for empowerment of women. NASHER Journal. 9(1), 115-119

World Bank (1999)“Nigerian Consultations with the Poor”. Report of the Global Synthesis Septmember 22-23, 1999.

Workshop 